\title{
Bacteriophages Against Pathogenic Bacteria and Possibilities for Future Application in Africa
}

This article was published in the following Dove Press journal:

Infection and Drug Resistance

\section{Tesfaye Kassa (D)}

School of Medical Laboratory Science, Institute of Health, Jimma University, Jimma, Ethiopia
Correspondence: Tesfaye Kassa

School of Medical Laboratory Science, Institute of Health, Jimma University, P.O.

Box 788, Jimma, Ethiopia

$\mathrm{Tel}+251931057195$

Email ktes36@gmail.com

\begin{abstract}
Bacteriophages (phages) are viruses that infect prokaryotic cells. Phages exist in many shapes and sizes with the majority of them being less than $100 \mathrm{~nm}$ in size. Essentially, the majority of phages identified are double-stranded DNA virions with the remaining few being found as RNA or single-stranded DNA viruses. These biological entities are plentiful in different environments, especially in wet sources. Treatment of a bacterial disease using phage application has been documented in the pre-antibiotic era. Different studies have emerging to value the efficacy of phage use in in-vitro and in-vivo based systems against specific bacterial agents of humans, animals or plant diseases. The process represents a natural and nontoxic framework to avert infections due to pathogenic and antimicrobialresistant bacteria. Most of the published researches on the usefulness of phages against disease-causing bacteria (including antimicrobial-resistant strains) of humans, animals or plants are emerging from the US and European countries with very few studies available from Africa. This review assesses published articles in the area of phage applications against pathogenic or antimicrobial-resistant bacteria from experimental, clinical and field settings. The knowledge and skill of isolating lytic phages against bacteria can be operational for its simpler procedures and economic benefit. Future studies in Africa and other emerging countries may consider in-house phage preparations for effective control and eradication of pathogenic and multidrug resistant bacteria of humans, animals and plants.
\end{abstract}

Keywords: phage therapy, antimicrobial-resistant bacteria, lytic phage, Africa

\section{Introduction}

Bacteria are prokaryotic micro-organisms that in their life processes evolve to turn into antibacterial resistant traits. The advent of antibacterial-resistant strains in the world creates a grave challenge and cost to lives around the world, especially in most parts of developing countries. ${ }^{1}$ Bacteriophages (equally named "phages") are viruses that live on bacteria and they are plentiful biological entities exceeding the sum of all bacteria by more than ten times in different environments, with a predominance in wet soils and water bodies. ${ }^{1}$

The first bacteriophage activity was revealed at the beginning of the twentieth century, independently by Twort in 1915 and d'Herelle in $1917 .^{2}$ The research on phage therapy flourished in the 1920s, mainly in Eastern Europe, predominantly in the early Soviet Union and Poland. ${ }^{3,4}$ Phage applications in the control and eradication of disease-causing bacteria were practiced before the discovery of antibiotics. ${ }^{2}$ Since these phages constitute the most dominant form of life in the biosphere, there are well-adapted virulent or lytic viruses present in every place capable of destroying pathogenic bacteria and multidrug resistant strains. ${ }^{5,6}$ 
Thus, understanding about bacteriophages and their use in resource limited settings in Africa may be an appropriate, affordable and economical alternative available from environmental sources. The price tag for medicines are usually costly in developing countries including in Africa where there are low per capita expenses for health. ${ }^{7}$ Ever since the discovery of antibiotics, bacteriophages have to be first recovered from different environmental sources and then diverse traits of the virus assessed against the identified bacteria or related strain. Essentially, the genome of the virus has to be checked or characterized to ensure their safety for human, animal or plant organisms. ${ }^{8}$ Recently available studies in the area of phage isolation and their use in phage therapy or biocontrol with its relevance for Africa are reviewed here.

Phages have some advantages compared to antibacterial antibiotics as an alternative therapy because the viruses can precisely mark bacteria and kill without interacting with the defense system of the infected organism as well as with the normally existing microbial flora. ${ }^{9}$ They are less likely to become resisted by the bacteria as the viruses tend to evolve faster than the bacteria. Hence, phages have an enhanced advantage to avoid the emergence of resistance. On the other hand, a blend (cocktail) of different bacteriophages can be administered to an infected organism to curtail further emergence of resistance. ${ }^{10}$ Unlike most antibacterial agents that have broad activity, bacteriophages have generally narrower host ranges. ${ }^{11}$ This property of phages can be taken as a beneficial trait because chemical antibacterial antibiotics usually harm endogenous microbial flora from the affected organism (human, animal or plant) subsequently may result in opportunistic or super infections contrary to phage therapy. ${ }^{12}$ It is imperative to underscore that phages can operate efficiently against antibacterial sensitive as well as resistant pathogens with more powerful action in the later types. ${ }^{13}$ Further advancement in the manipulation of bacteriophage genomics may pave the way to scrutinize phage encoded products such as endolysins. ${ }^{14}$ These enzymes are expressed at the completion of phage assembly in bacterial cells. Since the release of numerous assembled phage particles within bacterial cells are opposed by a stronger bacterial cell wall skeleton from the intracellular side, endolysins are expressed to break it. This kind of phage enzyme may become a novel candidate of antibacterial agent in the future.

The review tries to discuss the overall uses of phage to control and eradicate pathogenic bacteria from humans, animals, plants, and other conditions. In recent times, the application of phage as a treatment or biocontrol is being considered because of the comparative advantage to find them in numerous sources of the environment against antimicrobial resistant (AMR) bacteria that are continually emerging. ${ }^{15}$ The term biocontrol is usually used to define when phages are employed on food and other environment orientated applications. On the other hand, phages when employed as a substitute to antimicrobial antibiotics in the clinical and veterinary practice, it is best defined as phage therapy. In this review, the two terms were probably used alike.

\section{Biology of Bacteriophages}

Bacteriophages, as a member of the viruses, are the most plentiful of all biological entities and they live on bacteria to replicate. ${ }^{2}$ Each kind of the virus targets a specific bacterial species or strain and so has a narrow host range. Infrequently, phages extend to include more than one bacterial species as its own host. This has been particularly exhibited among phages against members of Enterobacteriaceae that tend to cross-genus and so have broad host ranges. ${ }^{16,17}$ Phages cannot infect eukaryotic cells as the surface properties of these cells are different from prokaryotic (bacteria) fine cell structures. Hence, phage entry into a eukaryotic organism system does not damage its cells.

Each virus particle is composed of a protein coat and tightly packed DNA or RNA genetic information with the DNA virus types accounting for over $97 \%$ of all studied phages worldwide. ${ }^{3}$ They exist in many shapes and sizes with the majority being tadpole-like appearance. The "head" part has an icosahedral or isometric shape and the "tail" part has terminal hair like (fiber) structures (Figure 1). Architecturally, the tail fibers are the one that interact specifically with the bacterial cell wall or outer membrane surface molecule receptors to initiate bacterial infection. Phages are extremely simple but are a diversified cluster that evolve faster than bacteria. According to current updates by the International Committee on the Taxonomy of Viruses (ICTV), phages that live on bacteria (excluding the cyanobacteria) are classified into 14 families with over five potential families pending classification. ${ }^{18,19}$ Over 5500 phages described in scientific publications have been examined under electron microscope. Almost all important phages associated with bacteriophage therapy are a member of the order Caudovirales. All members of the order are double stranded DNA tailed phages that contain three 


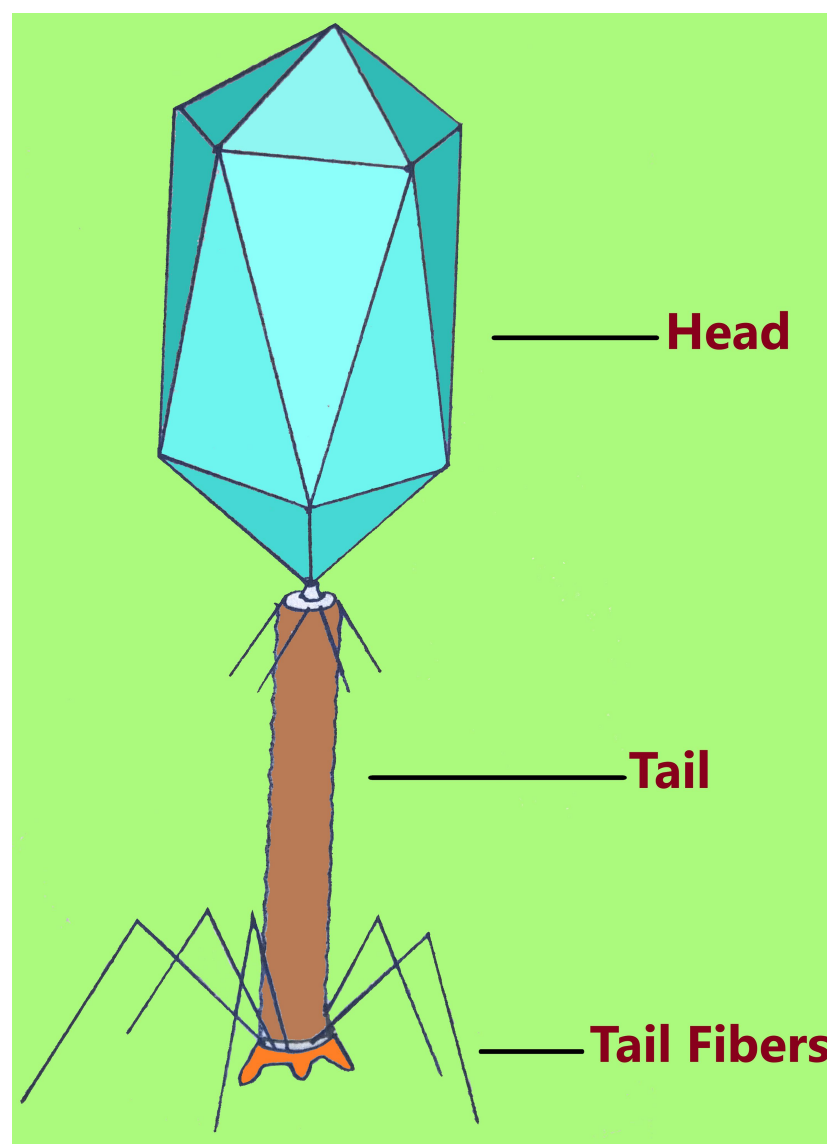

Figure I The great majority of phages assigned in the order Caudovirales have an isometric head with size varying from 20 to $200 \mathrm{~nm}$; and more than $97 \%$ of phages have varying length of tail and tail fibers.

families including Siphoviridae (phages with long, flexible tails); Myoviridae (phages with double layered contractile tails); and Podoviridae (phages with short, stubby tails). The other morphological forms of phages from other family groups appear as filamentous, polyhedral, and pleomorphic shaped representing less than four percent of all identified phages, some of which are very small in size. ${ }^{20}$

In general, bacteriophages can be subdivided into two key categories based on life cycle strategy they follow on their hosts as shown in Figure 2. The first groups are lysogenic viruses which infect bacterial cells followed by integration of their DNA information into the DNA of bacteria. Therefore, the bacteria reproduce asexually in conjunction with the integrated bacteriophage information. The sequence of a lysogenic virus infection continues for quite a lot of the generation of the bacterial cell. The viral genome replicates together with the bacterial DNA and as a result, all the bacterial progeny reproduced will carry the virus information. This process can play a vital part in the transfer of genetic traits from one progeny of bacteria to the other, for example, antimicrobial resistance and bacterial invasiveness factors. The lysogenic cycle continue endlessly unless exposed to adverse conditions that can terminate the lysogenic phase (Figure 2). The termination causes expression of the phage nucleic acid to initiate lytic cycle. ${ }^{21}$ However, this lytic phase can reverse to a lysogenic cycle. Among adverse conditions that activate the lytic phase include exposure to UV light, mutagenic chemicals, depletion of nutrients and desiccation. Generally, lysogenic phages are not suitable candidates for the application of bacteriophage therapy with few exceptions. ${ }^{22}$

The second groups are lytic viruses that interact, enter and complete their life cycle in the bacterial cell and finally lyse the host cell. Lytic phages, unlike lysogenic groups, do not integrate their DNA material into the DNA of the bacteria. The viruses use macromolecular machineries of the bacteria for replication and release a collection of several viral particles after breaking the cell wall of the bacteria in a comparatively fixed latent period. The newly released virions in the extracellular phase spread to begin new infections on other bacterial cells (Figure 2). Such virulent types of phages are good candidates in bacteriophage therapy because of their destruction and shorter replication cycle. ${ }^{22,23}$

A number of recent reports have appeared worldwide describing the part of lytic phages in the eradication of pathogenic infections in animals, plants and other in-vitro animate or inanimate structures. ${ }^{24-32}$ Basically, the virulent groups of bacteriophages are bactericidal in action, with very minimal reactions to mammalian systems that can boost its number in the presence of bacterial host. Thus, understanding the feature, isolation and handling techniques of bacteriophages from various environmental sources are an essential first part in the research and development of phage therapies. Further characterization and processing of bacteriophage is essential to assume as a candidate therapy against pathogenic bacteria. For instance, in external surface applications as in the case of a wound due to a burn or from inanimate objects, the process to get rid of bacteria can be relatively simple. Whereas to get rid of systemic bacterial infections in humans or animals, the material for application has to be cleaned from bacterial debris, other biological and chemical impurities that otherwise might be toxic. ${ }^{33}$

\section{Genetically Modified Phages}

Lytic or virulent bacteriophages are preferred principally for phage therapy to avoid lateral gene transfer. In most literature, the best candidates in phage therapy are DNA viruses with very negligible entrants from RNA bacteriophages. The 


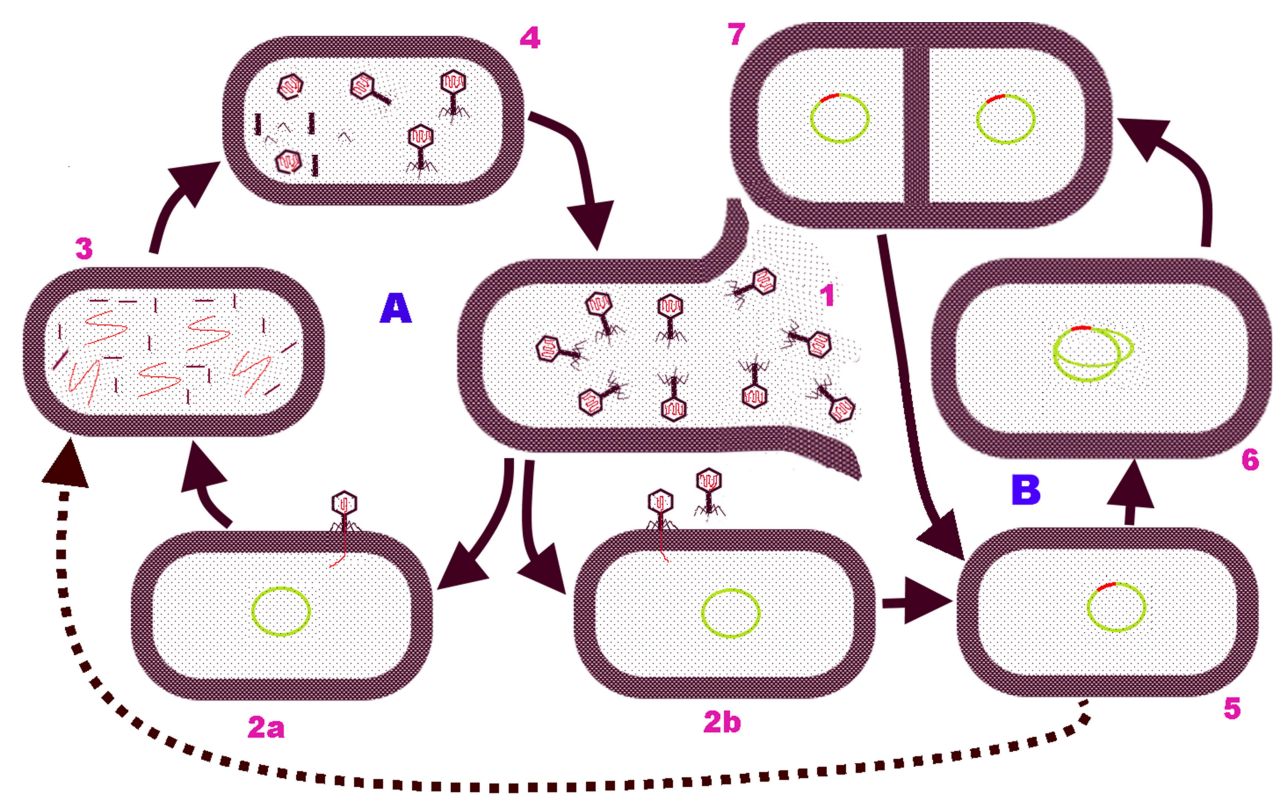

Figure 2 Bacteriophage life cycle schematic representation: the two main categories of phage life cycles against a bacterial host in [A] Lytic and [B] Lysogenic cycles. I, Bacteria cell wall lysed to release infective phage particles due to mature bacteriophages and their enzymes; $2 a \& 2 b$, Bacteriophages attach to specific cell wall receptor, penetrate, and insert its DNA. In lytic phage cycle (in 2a), phage genome redirects the bacterial cell machineries for synthesizing phage specific products; 3 , Phage DNA and various proteins including capsid protein, tail fibers, sheaths, and base plates are produced; 4, Empty phage heads are packed with DNA, assembly of phage parts. In lysogenic Cycle (in $2 b$ ), the phage genome integrates into the bacterial chromosome (5); 6, Integrated phage genome (prophage) replicates along with the bacterial DNA prior to binary fission; 7, Binary fission is to complete and each cell has the phage DNA incorporated in the bacterial DNA. But, following induction of the prophage into the lytic phase, the integrated phage DNA (in 5) is excised from the bacterial cell genome and follow the lytic cycle (broken arrow line) irregularly leading to the release of phage particles.

diversity of bacteriophages in structure and genetic composition are noted against a distinct species of bacteria. For instance, the most commonly known bacterium, Escherichia coli, has several counts of coliphages in the gut. ${ }^{34}$ This is because distinct phages against a distinct bacterial strain use a specific cell surface receptor. Phages with narrow host ranges are the commonest ones and most of them tend to demonstrate specificity to a species level with still fewer others specific to strains of bacteria. Rare broader host range phages have also been described that can cross species barrier to infect different bacterial species but they are the exceptions. ${ }^{16}$ In the current advancement of molecular genetics, there have been efforts to manipulate and reprogram phages component after sequencing and characterizing in order to use them for treatment. ${ }^{35,36}$

The current and future development in the science of manipulating phage genetic material may direct the way for a broader host range construction of phage for treatment and biocontrol purposes. Di Giovine and his associates ruled out that bacteriophages were manipulated genetically to infect even mammalian cells where the viruses were not known to infect eukaryotic cells; however, the virus did not multiply inside the mammalian cells after infection. ${ }^{37}$ Further studies reported bacteriophages were engineered to express active bacteria degrading enzymes. Lu and Collins manipulated a biofilm degrading enzyme that acted concurrently on the adhered bacterial cells in the interior of the biofilm setting as well as to the extracellular polymeric substance deposits of the biofilm. ${ }^{38}$

\section{Phage Therapy in Medical Science}

The cost of basic medical care alone is expensive in developing countries excluding the costs to buy effective antibiotics to counter antibacterial resistance. ${ }^{1,7}$ Based on the information found from the World Health Organization, ${ }^{39}$ significant groups of the population living in developing countries do not have enough money to purchase a substitute of commonly available generics. Because of this, those people usually continue with sub dosage antibiotics, the drugs are not taken over the recommended time period or the product may be a falsified one that in all cases transcend to the emergence of antibacterial resistance.

During the past 30 years, the emergence and spread of antimicrobial resistance has been well recognized around the world. However, the search and development of novel antibiotic classes has not begun to satisfy the demand, in spite of the progress in modern biotechnology or nanotechnology. Most of the new antibacterial products joining the market were developed from known precursors of antibacterial agents. ${ }^{40}$ 
Since the level of antibacterial resistance increased considerably from the 1980 s to 1990 s, the search for alternative treatments grew, but with few results, and different scientists and companies turned to phage isolation for use in treatment. ${ }^{41,42}$ Nevertheless, the absence of the proper characterization of bacteriophages, absence of placebo versus case treatment controlled trials, absence of proper statistical analysis, and the economic stance of the countries where the assessment was made mattered to obtain a full evidence of quality and authenticate the effectiveness of phages application against bacterial pathogens. ${ }^{43,44}$ In some circumstances, phages were used in experimental or real settings alone or blending it with antibacterial agents despite that the latter may have some antagonistic effect. ${ }^{45,46}$ Some antibacterial drugs arrest actively reproducing bacteria and in due course phages skip their lytic activity. Phages can also be employed as disinfection agents on medical objects to prevent the occurrence of health care associated infections. ${ }^{43}$

Phages have been accepted in clinical use in the Eastern countries unlike the Western blocs. However, recently phage related activities have increased in Western countries too resulting in a significant surge in bacteriophage related scientific papers. ${ }^{10,47}$ Schooley and his colleagues reported the first patient from the United States who was infected by multidrug resistant Acinetobacter baumannii that has been given with a blend of phages as all available antibiotic choices were ineffective. ${ }^{10}$ The patient recovered from deteriorating health to normalcy following the removal of the bacterium upon intravenous and percutaneous administration of personalized-based phage therapy. Serious burns in humans have been reported to be the causes of death within the first two days due to Pseudomonas aeruginosa infection. ${ }^{48}$ Survivability due to phage therapy has been shown by McVay and his associates. Markoishvili and associates reported progressive wound healing completely in $70 \%$ of the ninety six patients whose wounds were covered with a phage enclosed matrix. ${ }^{49}$ This recovery was connected with a significant shrink in the number of the particular bacteria in the wound. Additional representative experimental or therapeutic works done in human are presented in Table 1.

Although some phage containing preparations have been produced in Western countries during the 1950s and 1960s, it was not continued with vigor as new antibiotics have appeared widely on the market as a miracle bullet against bacteria. ${ }^{50}$ One of the primary reasons that played a role in the weakening of attention in phage therapy in the Western bloc was a reliability problem. The scarcity of suitably directed studies and the lack of well-established and standardized testing protocols restricted the value of phage therapy.

As bacteriophages are sub-microscopic entities, there was a difficulty in documenting rigorous biological features of the virus as a candid choice. These include the absence of tools to properly visualize the particle, the abundant test parameters for biophysical features, and nucleic acid associated factors. In addition, phage product manufacturing related difficulties also complicate the studies on the use of phage therapy. Since phage particle survivability is markedly affected by external factors, particularly temperature, there were no modern facilities like refrigerators, ultra freezers, lyophilizer, etc, to keep phage preparations effective. $^{15,51}$

The use of phage in the eradication of pathogenic bacteria has the prospect to be a game changer for medical care in most parts of Africa. The evidence from the $\mathrm{WHO}^{39}$ shows that infections and parasitic diseases are among the leading factors causing the death of 20 million people in developing countries per annum. Each year as many as 8 million children below the age of 5 years die due to acute bacterial respiratory tract infections caused by Streptococcus pneumoniae and Haemophilus influenzae type b, and diarrheal illnesses caused by Shigella species, Vibrio cholerae and a number of other enteric bacteria like Escherichia coli strains. ${ }^{52}$ Predominantly in Africa and particularly in sub-Saharan Africa, bacterial dysentery is commonly reported as a cause of substantial incidence and death. ${ }^{53}$ There have been reports of epidemics caused by antimicrobial-resistant Shigella dysenteriae since the 1970s from African nations. ${ }^{52,54}$ By the 1990s, several of these epidemics from the developing world were caused by strains resistant to all antibiotics available. ${ }^{54}$ Access to rather newly upgraded antibiotics is often limited in public services in Africa due to their higher costs.

Whereas bacteriophages can still become a locally and rationally produced remedy even in a personalized-based approach at a health facility level in African settings, conveying awareness and knowledge about the viruses is the first important part. Obtaining lytic bacteriophages is an easier effort and ideal candidate to combat diseasecausing bacteria at a basic medical care level. Very little is studied about the use of phages in therapeutic or experimental practice by African countries including Ethiopia. ${ }^{55-59}$ In the early 20th century, Felix d'Herelle 
Table I A Display of Some of the Experimental or Therapeutic Work Done Using Bacteriophages Against Disease Causing Bacteria of Humans, Animals, and Plants

\begin{tabular}{|c|c|c|c|c|}
\hline $\begin{array}{l}\text { Target } \\
\text { Bacterium }\end{array}$ & $\begin{array}{l}\text { Host } \\
\text { Organism }\end{array}$ & Type of Infection & Phage Administration Route and Outcome & Reference \\
\hline $\begin{array}{l}\text { Staphylococcus } \\
\text { aureus, antibiotic } \\
\text { resistant strain }\end{array}$ & $\begin{array}{l}\text { One Human } \\
\text { patient ( } 65 \text { years } \\
\text { old Female) }\end{array}$ & $\begin{array}{l}\text { Corneal abscess and interstitial } \\
\text { keratitis (Left-eye) }\end{array}$ & $\begin{array}{l}\text { Topical (in the form of eye drop and nasal spray) and } \\
\text { systemic (intravenous) phage for } 4 \text { weeks at Phage } \\
\text { Therapy Center, Tbilisi, Georgia using phage SATA- } \\
8505 \text { (ATCC PTA-9476). Culture from ocular and } \\
\text { nasal confirmed as negative after } 3 \text { months. }\end{array}$ & [114] \\
\hline $\begin{array}{l}\text { Staphylococcus } \\
\text { aureus } \\
\text { (Multidrug } \\
\text { resistant) }\end{array}$ & $\begin{array}{l}\text { Six Diabetic } \\
\text { Human cases }\end{array}$ & Diabetic Foot Ulcer & $\begin{array}{l}\text { Topical applied phage Sb-I preparation once weekly } \\
\text { for } 7 \text { months and one case for } 18 \text { months. The } \\
\text { amount of phage solution applied varied from } 0.1 \text { to } \\
0.5 \mathrm{~mL} \text { depending on area of the ulceration. All treated } \\
\text { patients recovered without amputation. }\end{array}$ & [115] \\
\hline Escherichia coli & $\begin{array}{l}\text { Human } 40 \text { male } \\
\text { infant patients } \\
\text { (6-24 months } \\
\text { old) }\end{array}$ & $\begin{array}{l}\text { Diarrhea resulting in loss of fluids } \\
\text { and electrolytes }\end{array}$ & $\begin{array}{l}\text { Placebo controlled clinical trial, Oral administration of } \\
\text { (Commercial Russian preparation) coliphage } 10^{9} \mathrm{PFU} / \\
3 \text { times/day/4 days } \\
\text { There was no significant clinical benefit observed } \\
\text { between control and test group. }\end{array}$ & [116] \\
\hline $\begin{array}{l}\text { Pseudomonas } \\
\text { aeruginosa }\end{array}$ & I Male patient & $\begin{array}{l}\text { Mediastinal and aortic graft } \\
\text { infection complicated by } \\
\text { P. aeruginosa }\end{array}$ & $\begin{array}{l}\text { Local admin of phage and antibiotic in the } \\
\text { mediastinum. } \\
\text { Complete absence of the bacterium confirmed and no } \\
\text { recurrences arisen in later period. }\end{array}$ & [27] \\
\hline $\begin{array}{l}\text { Vibrio } \\
\text { parahaemolyticus } \\
\text { (MDR) }\end{array}$ & Murine & $\begin{array}{l}\text { Sepsis Developed after mouse } \\
\text { challenged with LD } 50(2.0 \times \\
\left.10^{7} \mathrm{CFU} \text { per mouse }\right)\end{array}$ & $\begin{array}{l}\text { Each mouse was treated with a single Intraperitoneal } \\
\text { injection of }\left(2.0 \times 10^{8} \mathrm{PFU} \text { per mouse }\right) \text { and oral }\left(2.0 \times 10^{8}\right. \\
\text { PFU per mouse }) \text { phage administered. Phage-treated mice } \\
\text { displayed protection from the infection and survived } \\
\text { lethal intraperitoneal and oral bacterial challenges. } \\
\text { Mortality was reduced by } 92 \% \text { and } 84 \% \text {, respectively. }\end{array}$ & {$[117]$} \\
\hline S. aureus & Rabbit & $\begin{array}{l}\text { Wound infection when rabbit was } \\
\text { injected subcutaneously (s.c.) with } \\
\text { S. aureus }\left(8 \times 10^{7} \mathrm{CFU}\right) \text {. }\end{array}$ & $\begin{array}{l}\text { S.c. co-administration of phage }\left(2 \times 10^{9}\right) \text { PFU along with } \\
\text { S. aureus prevented abscess formation in rabbits. Phage } \\
\text { found increased in number at the infected tissues. }\end{array}$ & [118] \\
\hline E. coli & $\begin{array}{l}\text { Chickens Three- } \\
\text { week-old }\end{array}$ & $\begin{array}{l}\text { Colibacillosis due to } E \text {. coli having } \\
5.5 \times 10^{8} \mathrm{CFU} / \mathrm{mL} / \text { bird orally } \\
\text { given }\end{array}$ & $\begin{array}{l}\text { Spraying phage on the litter reduced mortality of the } \\
\text { broilers significantly. } \\
\text { Drop in the number of } E \text {. coli count among fowl flocks was } \\
\text { noted. }\end{array}$ & [119] \\
\hline $\begin{array}{l}\text { Pseudomonas } \\
\text { plecoglossicida }\end{array}$ & $\begin{array}{l}\text { Ayu fish } \\
\text { (Plecoglossus } \\
\text { altivelis) }\end{array}$ & $\begin{array}{l}\text { Bacterial hemorrhagic ascites } \\
\text { disease }\end{array}$ & $\begin{array}{l}\text { Oral challenge. Lower mortalities ( } 26.7 \%) \text { were observed } \\
\text { among phage administered groups, in contrast to the } \\
\text { control phage-untreated ( } 90-100 \%) \text { group. }\end{array}$ & [120] \\
\hline $\begin{array}{l}\text { Aeromonas } \\
\text { hydrophila }\end{array}$ & Fish & Freshwater fishes septicemia & $\begin{array}{l}\left.\text { Phage was added }\left(10^{7} \mathrm{CFU} / \mathrm{mL}\right) \text { in water tanks (MOI of } 10\right) \text {. } \\
100 \% \text { fatal in } 3 \text { to } 4 \text { days in control but } 56.7 \% \text { in phage treated } \\
\text { group. }\end{array}$ & {$[12 \mid]$} \\
\hline E. coli OI57:H7 & $\begin{array}{l}\text { Cattle, sheep and } \\
\text { mouse }\end{array}$ & $\begin{array}{l}\text { Carriage reduction of } E \text { coli O I57: } \\
\mathrm{H} 7\end{array}$ & $\begin{array}{l}\text { Phage rectally administered. It resulted in the decline } \\
\text { of the average number of } E \text {. coli OI57:H7 compared } \\
\text { to control in the animals. }\end{array}$ & [122] \\
\hline Dickeya solani & Potato & $\begin{array}{l}\text { Rotting or Blackleg in potato } \\
\left(10^{5} \mathrm{CFU} / \text { tuber used }\right)\end{array}$ & $\begin{array}{l}\text { Phage (at } 100 \mathrm{MOI} \text { ) resulted in the reduction of soft } \\
\text { rot of inoculated tubers in the laboratory and in field } \\
\text { setting trials. Potato crop yield increased. }\end{array}$ & [123] \\
\hline
\end{tabular}


Table I (Continued).

\begin{tabular}{|c|c|c|c|c|}
\hline $\begin{array}{l}\text { Target } \\
\text { Bacterium }\end{array}$ & $\begin{array}{l}\text { Host } \\
\text { Organism }\end{array}$ & Type of Infection & Phage Administration Route and Outcome & Reference \\
\hline $\begin{array}{l}\text { Ralstonia } \\
\text { solanacearum }\end{array}$ & Tomato & Bacterial wilt, & $\begin{array}{l}\text { Three Phages alone or in combination at } 0.5-5.0 \times 10^{8} \\
\text { PFU/mL resulted in a rapid decrease in the host bacterial } \\
\text { cell density. Pretreatment of tomato seedlings with one of } \\
\text { the phage drastically limited penetration, growth, and } \\
\text { movement of root-inoculated bacterial cells. All RSLI- } \\
\text { treated tomato plants showed no symptoms of wilting } \\
\text { during the experimental period, whereas all untreated } \\
\text { plants had wilted by } 18 \text { days post infection. }\end{array}$ & [124] \\
\hline $\begin{array}{l}\text { Xanthomonas } \\
\text { campestris pv. } \\
\text { vesicatoria }\end{array}$ & Tomato & Bacterial spot & $\begin{array}{l}\text { Specific bacteriophages in field setting was effective } \\
\text { against } X \text {. campestris pv. vesicatoria bacterial spot pathogen } \\
\text { in three experiments provided better disease control } \\
\text { than copper-mancozeb or untreated control. Phage \& } \\
\text { plant activator mix resulted in superior control. }\end{array}$ & [125] \\
\hline Xylella fastidiosa & Grapevines & Pierce's Disease & $\begin{array}{l}\text { Problem of bacteria in grapevines was remarkably } \\
\text { condensed before and after inoculation of a four } \\
\text { phage cocktail. The symptoms can be stopped using } \\
\text { phage treatment post infection as well as applying } \\
\text { phage prophylactically to grapevines. }\end{array}$ & [126] \\
\hline $\begin{array}{l}\text { Xanthomonas } \\
\text { axonopodis pv. } \\
\text { allii }\end{array}$ & Onion & Xanthomonas leaf blight of onion & $\begin{array}{l}\text { Weekly and biweekly applications of phage in field } \\
\text { setting could decrease disease severity. The result was } \\
\text { comparable to copper-mancozeb applications weekly. }\end{array}$ & [127] \\
\hline $\begin{array}{l}\text { Pectobacterium } \\
\text { carotovorum ssp. } \\
\text { carotovorum }\end{array}$ & Lettuce & $\begin{array}{l}\text { Soft rot and stem rot. } \\
\text { ( } 10^{8} \mathrm{CFU} / \mathrm{mL} \text { bacteria sprayed). }\end{array}$ & $\begin{array}{l}\text { High titer phage applied after one days of post- } \\
\text { infection could remarkably decrease symptom } \\
\text { development on lettuce plants (in a Greenhouse) }\end{array}$ & [128] \\
\hline $\begin{array}{l}\text { Streptomyces } \\
\text { scabies }\end{array}$ & Radish & Common scab & $\begin{array}{l}\text { Phage could avert symptoms advance in radish seedlings. } \\
\text { Nearly } 30 \% \text { more weight gain compared to untreated } \\
\text { group. }\end{array}$ & [129] \\
\hline $\begin{array}{l}\text { Xanthomonas } \\
\text { axonopodis pv. citri }\end{array}$ & Grapefruit & Asiatic citrus canker. & $\begin{array}{l}\text { Five greenhouse experiments utilizing phage usage } \\
\text { decreased disease severity by } 59 \% \text {. }\end{array}$ & {$[130]$} \\
\hline
\end{tabular}

treated four plague patients in Alexandria, Egypt. ${ }^{15}$ The use of phages was documented in Egypt between the 1980s and 1990s by treating burn wound related infections in humans. ${ }^{60}$ Phage therapy research should gain momentum in leading African research and medical facilities as antibiotic research in big companies comes to a near stop. New antibiotic production demands lavish spending to go through research and development to the market place. ${ }^{61}$

\section{Phage Therapy in Veterinary Science}

Nearly fifty percent of all different antibacterial agents produced around the world are consumed in animal treatments. Some of the commonest antibacterial drugs with similar classes in human medicines are vended freely over the counter for treatment and growth promotion including in the latest husbandry. ${ }^{62,63}$ Those extensively available veterinary antimicrobial drugs procured over the counter in several African states are contributing to the rise of cross resistant bacteria in human or conversely from human to animals. ${ }^{64}$ It has been shown that AMR bacteria from humans, who have not taken the drug, was found but initially detected in animal products like meat and milk. There may not be fundamental evidence but the spread of resistant bacterial strains among human and animals adds difficulties in antibiotic use in future veterinary or medical fields. According to the review by Golkar and his team, phage therapy is not only a potential solution against antibacterial resistant strains but it also does not thwart the use of antibacterial agents as a flesh gaining scheme in animal husbandry. ${ }^{65}$ 
Felix d'Herelle was the first known scientist to discover and use phages in veterinary medicine., ${ }^{2,66}$ D'Herelle is considered the father of bacteriophages as he discovered the first activity of bacteriophages in 1917, and later in 1919, he examined the effectiveness of phage in relieving chickens from Salmonella typhoid illness. He observed that the phages administered among chickens reduced mortality successfully, which provoked other scholars to study the potential utility of phage therapy in controlling and curing other experimental or wildly happening bacterial infections in animals. ${ }^{67}$ In that consideration, the safety issue and applicability of phages have been described in various infections of animals due to bacterial etiologies ${ }^{23}$ (Table 1).

The use of phage therapy among livestock has been rekindled during the 1980s following the results of experiments by Smith and Huggins. ${ }^{68,69}$ Smith and his colleagues verified that administration of one dose of phage was as equal as several doses of antibacterial drugs in handling infections due to Escherichia coli in mice as well as in calves. Other subsequent trials established that phages are usable in prophylaxis for a particular etiology or for treatment of bacterial infections of the intestine and other body systems in a variety of livestock, including cattle, sheep, chickens, pigs, and fishes. ${ }^{66,70}$ A success rate of $90 \%$ to $100 \%$ rescue has been achieved in phage treated mice and chicken against Salmonella infections. ${ }^{71,72}$ It was shown that a significant fall in the number of bacterial pathogens has been revealed. This was linked to the good prognosis of livestock infections after administration of phages. The reduction of the bacterial count after the administration of phage was equivalent to the decline observed after the complete course of antibiotics. For instance, a $99 \%$ decline in the bacterial cell count of Campylobacter on marketed chickens has been proven upon use of specific phages. This reduction in the bacterial cells from marketable chickens likely reduced the occurrence of campylobacteriosis among human in excess of thirty fold. ${ }^{73}$ In general, application of phages in animals did not induce known serious complications as compared to the numerous side effects with the use of broad spectrum antibacterial agents. ${ }^{43}$ Hence, there is lots of room to justify the application of phages in veterinary medicine in Africa.

\section{Phage Biocontrol in Bacterial Diseases of Plants}

Diseases of plants due to bacterial infections is a wellrecognized problem. Several of the known bacterial etiologies affecting plants include, Pseudomonas syringae that cause speck, spot and canker diseases; Agrobacterium tumefaciens causing crown gall; Xanthomonas campestris that cause black rot and bacterial leaf spot; Ralstonia solanacearum as a cause of bacterial wilt of potato; Xanthomonas oryzae causing rice bacterial blight; Xanthomonas axonopodis pv. manihotis causing cassava bacterial blight; Erwinia amylovora as a cause of fire blight; Xylella fastidiosa as the cause of Pierce's disease of grapevine, citrus multicolored chlorosis, almond leaf scorch disease; Dickeya dadantii as a cause of soft rot and black leg disease of potato; and Pectobacterium carotovorum and P. atrosepticum causing soft rot and blackleg, etc. ${ }^{74}$ Epidemiologically, most of these bacterial agents are known to affect plants in African soil.

The use of bacteriophages in agriculture is well documented to deal with plant bacterial infections like Xanthomonas citri that affect Citrus species, which otherwise are treated with antibiotics. ${ }^{75}$ Studies in field settings found that bacteriophages were efficacious in heavily reducing the occurrence of leaf blight of onion, as well as tomato bacterial spot due to Xanthomonas species. ${ }^{76,77}$ In recent times, researchers in numerous industrialized countries are busy recovering specific phages from the environment (see in Table 1).

The current trend to use phages in the treatment of some agricultural food products has been shown by the Food and Drugs Administration (FDA) that has approved their use in the USA. ${ }^{78}$ Moreover, other trials on phage applications have also been described for several other crops including apple, onion, tomato, potato, pear, citrus fruit, and raspberry. ${ }^{79-81}$ It is important to note that the application of chemical antimicrobials affects the soil microbiology. ${ }^{82}$ Replacing these antimicrobials with bacteriophages will be an ecofriendly substitute for a sustainable agriculture, though no study has been found from Africa. It is important to anticipate that phage viability on plant leaf surfaces may be challenged by different physical factors such as UV (sun) light. Hence, evening or night time application can provide more effective bacteriophage treatments against plant bacterial pathogens. ${ }^{83}$

Civerolo and Kiel reported an $86 \%$ to $100 \%$ effectiveness of bacteriophages treatment against bacterial spot disease of peach seedlings due to Xanthomonas pruni compared to a control category. ${ }^{84}$ Erwinia amylovora is among the most frequently studied bacterial pathogen of plants associated with fire blight. Erskine used different bacteriophages against E. amylovora and observed that symptoms were delayed in pear slices used in the 
experiment. ${ }^{85}$ Subsequently, in the study of Ritchie and Klos in 1977, bacteriophages identified against E. amylovora was effectively applied to avert the occurrence of fire blight in apple seedlings that has been injected with the pathogenic E. amylovora. ${ }^{86}$ Numerous specific bacteriophages against the host E. amylovora were isolated from several fruits and soil sections sampled at the sites where there were fire blight displaying crops. ${ }^{80}$ Similarly, Gill and his associates ${ }^{87}$ isolated more than forty specific phages against Erwinia amylovora from multiple places in botanical gardens in the USA. Hence, the approach in the isolation of phage against common pathogens of plants shows the prospect to replicate in Africa.

The role of bacteriophage enzymes was also known to affect bacteria. For example, endolysins as described above $^{14}$ and polysaccharide depolymerase derived from specific phage has been reported. ${ }^{88}$ Endolysins are lytic enzymes that dismiss bacterial host cells thereby permitting the release of newly assembled viruses. The later enzyme disintegrates the extracellular polysaccharide substance of Erwinia amylovora that serve as a major virulence factor in plant disease. ${ }^{89}$ The bacterium without this extracellular polymeric (capsule) material is nonpathogenic to plants. In general, virulent bacteriophages or their products have been proven in the biocontrol of plant bacterial pathogens. Further study needs to be implemented in African settings to improve agricultural output for the rapidly growing population with the use of ecofriendly products.

\section{Environmental Factors on Bacteriophages}

Even though bacteriophages are abundantly available entities from a variety of environmental sources, their survival in different environments are influenced by physico-biochemical factors such as the level of $\mathrm{pH}$, ionic strength, temperature, moisture and host/bacteria concentration. ${ }^{51}$ Other factors from the bacteria infected organisms (humans, animals or plants) include the presence of neutralizing antibodies and other innate immune factors, and rate of phage distribution from the site of administration, etc and influence on phage activity. ${ }^{90}$ The propagation of numerous phage species is affected when $\mathrm{pH}$ is less than 4.5 despite the presence of ample bacterial cells. In human or animal systems, for instance, application of oral phage may be influenced by stomach acidity that negatively disturb the persistence of the phage and lead to loss of titer and treatment failure. ${ }^{91,92}$

Some bacteriophages are not isolatable in the classic bacterial culture media systems as bacteria are. This is because certain bacteria do not grow in artificial culture systems. However, with the accessibility of affordable genetic (DNA) sequencing methods in the 21 st century, it has caused a striking rise in the counts of available bacteriophage genomes from numerous samples by metagenomic studies. $^{93,94}$ This genomic assessment has helped in the discovery of novel bacteriophages and has helped the identification of genes from environmental samples encoding for important candidates in the control of pathogenic bacterial species such as endolysins. The study of bacteriophage genomes using a metagenomic approach may be a reliable and valued source of new lytic enzymes that may be operational in various fields of study albeit many of the phages carrying a particular gene of interest cannot be presently multiplied in laboratory conditions. ${ }^{22,95}$

The future of phage research seems brighter as there are several publications appearing despite the small amount of output seen from the African continent. With several thousand scientific publications dedicated to "Bacteriophages"96,97 or related to bacteriophages coming yearly in the past 10 years, ${ }^{98}$ this field of interest has developed from a forgotten undermined and marginalized research area to a key, extensive scientific topic of the $21^{\text {st }}$ century. This condition is not a surprise as AMR bacteria are growing extensively around the world. In addition, the use of phages other than phage therapy or biocontrol, they are used to trace the epidemiology of specific bacteria in particular difficulties, study the ecological fitness of their hosts, serving as genetic vector in molecular biology, typing of bacteria, as indicator of water treatment system, and in the study of biodiversity of complex environments. ${ }^{22,99,100}$ Bacterial infections occurring as outbreaks from humans, animals or environmental origins have been traced by different phenotypic methods among which the use of a panel of phages has been known. ${ }^{101,102}$ A phage typing method is employed in most investigations to provide understanding of the routes of transmission or reservoir of infection such as the typing of various strains of $S$. Typhimurium. ${ }^{102}$

\section{Industrial Scale Manufacturing of Bacteriophages}

Since the work on phage therapy continued in the former Soviet Union where the Institute of Bacteriophage, 
Microbiology and Virology in Tbilisi was the primary one founded in $1923,{ }^{3,4}$ and there were attempts variably to produce phage preparations. Since independence in 1991 from Russia, Georgia (Tbilisi) has continued the work on bacteriophage yet at staggering swing. In Georgia, phage therapy alone or accompanied with antibacterial agents was part of a common medical practice against community as well as hospital-acquired bacterial infections, as preventive prophylaxis, as preoperative application on skin surfaces, and as disinfection agent in disinfecting surgical rooms. The Institute in Tbilisi works with partners in the USA as well as collaborating with Georgian hospitals in order to employ phages to fight off hospital-acquired infections. Biopharm Ltd. Company in Georgia has the mission of manufacturing phage preparations in singleton to specific notorious bacteria like Staphylococcus or a blend of several phages preparations against enteric bacteria. All of the preparations produced in certain stocks were used only in the Georgian market. Phage associated production systems do not meet pharmaceutical quality standards and protocols described by the WHO and other requirements by several industrialized countries. ${ }^{103-105}$

In the former Soviet Union, there were other sites established for the large scale production of phage preparations in the late 1920s. One of the last developed phage products was called "Intestifag" which is still being produced, containing several strains, against different intestinal bacteria and another product from Biochimpharm. ${ }^{106}$ There were a few other countries in the Eastern world working on phages that have published in English to avail to the Western bloc. In clinical practice in Poland, some documented phage therapy was carried out in the 1980s. ${ }^{50}$

There are several other prominent companies manufacturing phage based products around the world. ${ }^{107}$ The majority of phage related companies, usable in preclinical research, biocontrol, patient care, and phage based bacterial detection, are located in North America, Europe and Asia including in the USA, Poland, Norway, UK, Portugal, Netherlands, France, Germany, Slovenia, China, India and Korea. There is no single center in Africa serving as a manufacturing hub for bacteriophage. The objective of most of the phage preparations may vary depending on location for local facility consumption or supplying other global centers. Manufactured products containing bacteriophages may be usable for treatment, for bacterial identification purpose, for enzyme production, genetic vector, etc. ${ }^{104,107}$
The manufacturing of phages at the industrial level requires good understanding of the biology of phage and growth requirements of host bacterium. This is followed by preparation of big vessel or bioreactor equipment to grow huge numbers of pure bacterial cells at optimum condition and in a defined or complex nutritive medium. These bacteria have to be infected by the specific bacteriophages obtained from the environment. Harvesting and purifying phage particles from the larger bacterial lysate is one of the more challenging and key, cost incurring steps especially when it is carried out on a large scale production system. ${ }^{47,108}$ The optimum situations for the propagation of virulent bacteriophages in voluminous vessel units can vary greatly depending on the feature of the host bacterium in the unit and the specific bacteriophage. The overall method for the propagation and production of virulent phages in the unit system may be adjustable to many bacteria to bacteriophage combinations. This is due to the fact that there is a variation in internal and external growth requirements of a variety of bacterial species. The various operating conditions including vessel volume capacity, appropriate optimum temperature, $\mathrm{pH}$ condition, ion strength, and nutrient composition to support bacterial growth are important considerations to note. ${ }^{109}$

Once a phage is purified, it is usually lyophilized or freezed and turned into various formulations without impacting the effectiveness and content. Stability of temperature up to $55^{\circ} \mathrm{C}$ and shelf lives of 14 months has been described for some types of phages in different formulation forms. ${ }^{109}$ Usually phages preparations are available in liquid forms and stored in refrigerated vials. However, most phage preparations in general are labile and have a shorter shelf life.

\section{Challenges in Phage Therapy}

Employment of phage therapy faces three main tests, including 1) the shortage of available data and randomized trials. This may result in diminished interest in phage therapy utility among professionals; 2) industrial scale production challenges, as phages are naturally found everywhere in environmental locations; and 3) difficulties in regulatory procedures, as there is no worldwide accepted quality assurance protocols.

Awareness on the natural existence of phages, their safety, and efficacy must be known to promote phage research and development as therapeutic agents against pathogenic and AMR bacteria. ${ }^{9}$ Furthermore, phage 
manufacturers are expected to adhere to certain agreed national and international protocols. The challenge of preserving phage stability in solution or other formulations from the point of manufacture to the point of delivery should be regulated. ${ }^{9,110}$ Even though phages are commercialized to minimal count and ratified as food additives, there are no established regulations that exist for the clinical use of phages in the developed world. ${ }^{22,110}$ From now on, a communication forum amongst the regulatory authorities, scientists, drug developers and safety agencies is desirable to design trials for general or personalizedbased phage therapy. Then, accelerating its endorsement in clinical practice. ${ }^{110-113}$

\section{Conclusions}

Because of the emergence of multidrug resistant strains of bacteria, the world has reached a grave point in the management of bacterial associated diseases. Novel antibiotics are not joining the market at the same rate that bacteria are evolving. This changing feature of bacteria from antibacterial susceptibility to the resistant form shields it from the action of different antibiotics. The results are shown that some extremely potent antibacterial drugs discovered were becoming hopeless and resisted by the bacteria in a short period of time. In such instances, the search for alternative approaches, such as the use of phage therapy, are gaining importance to control and eliminate pathogenic bacteria including multidrug resistant strains. The abundance of bacteriophages in our environment makes them relatively simple to isolate and characterize against pathogenic bacteria (at least in personalized cases of humans, animals or plants).

Phages, when properly selected and characterized, offer the most cost beneficial alternative to antibiotics in Africa. Bacteriophages key rewards as therapeutics are their capability to mark bacterial species or strains without any destructive consequence to the rest of microflora as well as the tissues of infected organism. Moreover, bacteriophages have propagation capability limited to the availability of the specific susceptible bacterial host. Thus, based on the clarified grounds, the following recommendations are proposed.

1. Incorporate courses on the basics of bacteriophage biology, isolation and characterization in higher education curriculum of natural science students in Africa.

2. Promote bacteriophage studies on phage therapy and biocontrol in different disciplines of the higher education system, especially in medical, veterinary, and agriculture sciences.
3. Accelerate effective bacteriophage therapy research and development centers in African countries.

\section{Acknowledgment}

I would like to thank Dr. Balcha Girma (MD), Harare, Zimbabwe and Dr Beira Hailu, Jimma University, for important discussions we made on the title frame and for the English editing. I am also grateful to Dr. David Dazhia Lazarus, veterinary epidemiologist at the National Veterinary Research Institute, Vom, Nigeria and currently in South Africa, for checking the scientific merit and editing this manuscript. Finally, I thank Jimma University library for availing me of some of the subscribed journals.

\section{Disclosure}

The author reports no conflicts of interest for this work.

\section{References}

1. Byarugaba DK. A view on antimicrobial resistance in developing countries and responsible risk factors. Int $J$ Antimicrob Agents. 2004;24(2):105-110. doi:10.1016/j.ijantimicag.2004.02.015

2. Kutter E, Sulakvelidze A, eds. Bacteriophages: Biology and Applications. CRC Press; 2005.

3. Abedon ST, ed. Bacteriophage Ecology: Population Growth, Evolution, and Impact of Bacterial Viruses. Cambridge University Press; 2008.

4. Chanishvili N. Phage therapy-history from Twort and d'Herelle through Soviet experience to current approaches. Adv Virus Res. 2012;83:3-40. doi:10.1016/B978-0-12-394438-2.00001-3

5. Ashelford KE, Day MJ, Fry JC. Elevated abundance of bacteriophage infecting bacteria in soil. AEM. 2003;69(1):285-289. doi:10.1128/AEM.69.1.285-289.2003

6. Batinovic S, Wassef F, Knowler SA, et al. Bacteriophages in natural and artificial environments. Pathogens. 2019;8(3):100. doi:10.3390/pathogens 8030100

7. Founou RC, Founou LL, Essack SY. Clinical and economic impact of antibiotic resistance in developing countries a systematic review and meta-analysis. PLoS One. 2017;12 (12):12. doi:10.1371/journal.pone.0189621

8. Clokie MRJ, Kropinski A, eds. Bacteriophages: Methods and Protocols, Volume 1: Isolation, Characterization, and Interactions. Humana Press; 2009. doi:10.1007/978-1-60327-164-6

9. Forde A, Hill C. Phages of life - the path to pharma. $\mathrm{Br}$ J Pharmacol. 2018;175(3):412-418. doi:10.1111/bph.14106

10. Schooley RT, Biswas B, Gill JJ, et al. Development and use of personalized bacteriophage-based therapeutic cocktails to treat a patient with a disseminated resistant Acinetobacter baumannii infection. Antimicrob Agents Chemother. 2017;61(10). doi:10.1128/AAC.00954-17

11. Hyman P, Abedon ST. Bacteriophage host range and bacterial resistance. Adv Appl Microbiol. 2010;70:217-48. doi:10.1016/ S0065-2164(10)70007-1

12. Azizian R, Nasab SDM, Ahmadi NA. Bacteriophage as a Novel Antibacterial Agent in Industry and Medicine. $J$ Paramed Sci. 2013; 4(4):93-101.

13. Chen LK, Kuo S-C, Chang K-C, et al. Clinical antibiotic-resistant Acinetobacter baumannii strains with higher susceptibility to environmental phages than antibiotic-sensitive strains. Sci Rep. 2017;7. doi:10.1038/s41598-017-06688-w 
14. Oliveira H, Melo LDR, Santos SB, et al. Molecular aspects and comparative genomics of bacteriophage endolysins. J Virol. 2013;87(8):4558-4570. doi:10.1128/JVI.03277-12

15. Summers WC. Bacteriophage therapy. Annu Rev Microbiol. 2001;55(1):437-451. doi:10.1146/annurev.micro.55.1.437

16. Hamdi S, Rousseau GM, Labrie SJ, et al. Characterization of two polyvalent phages infecting Enterobacteriaceae. Sci Rep. 2017;7 (1). doi:10.1038/srep40349

17. Born Y, Fieseler L, Marazzi J, Lurz R, Duffy B, Loessner MJ. Novel virulent and broad-host-range erwinia amylovora bacteriophages reveal a high degree of mosaicism and a relationship to enterobacteriaceae phages. Appl Environ Microbiol. 2011;77 (17):5945-5954. doi:10.1128/AEM.03022-10

18. Ackermann H-W. Phage classification and characterization. Methods Mol Biol. 2009;501:127-140. doi:10.1007/978-1-60327-164-6_13

19. ICTV. International Committee on Taxonomy of Viruses. ICTV; 2019. Available from: https://talk.ictvonline.org/taxonomy/p/taxon omy-history?taxnode_id=201904780. Accessed September 6, 2020.

20. Ackermann H-W. 5500 Phages examined in the electron microscope. Arch Virol. 2007;152(2):227-243. doi:10.1007/ s00705-006-0849-1

21. Hope CK, Packer S, Wilson M, Nair SP. The inability of a bacteriophage to infect Staphylococcus aureus does not prevent it from specifically delivering a photosensitizer to the bacterium enabling its lethal photosensitization. J Antimicrob Chemother. 2009;64(1):59-61. doi:10.1093/jac/dkp157

22. Fernández L, Gutiérrez D, García P, Rodríguez A. The perfect bacteriophage for therapeutic applications-a quick guide. Antibiotics. 2019;8(3):126. doi:10.3390/antibiotics803 0126

23. Alexander S, Barrow P. Phage therapy in animals and agribusiness. In: Kutter E, Sulakvelidze A, editors. Bacteriophages: Biology and Applications. CRC Press; 2005.

24. Abuladze T, Li M, Menetrez MY, Dean T, Senecal A, Sulakvelidze A. Bacteriophages reduce experimental contamination of hard surfaces, tomato, spinach, broccoli, and ground beef by Escherichia coli O157: H7. Appl Environ Microbiol. 2008;74 (20):6230-6238. doi:10.1128/aem.01465-08

25. Bardina C, Spricigo DA, Cortés P, Llagostera M. Significance of the bacteriophage treatment schedule in reducing Salmonella colonization of poultry. Appl Environ Microbiol. 2012;78 (18):6600-6607. doi:10.1128/aem.01257-12

26. Barrow P, Lovell M, Berchieri A. Use of lytic bacteriophage for control of experimental Escherichia coli septicemia and meningitis in chickens and calves. Clin Diagn Lab Immunol. 1998;5 (3):294-298. doi:10.1128/CDLI.5.3.294-298.1998.

27. Chan BK, Turner PE, Kim S, Mojibian HR, Elefteriades JA, Narayan D. Phage treatment of an aortic graft infected with Pseudomonas aeruginosa. Evol Med Public Health. 2018;2018 (1):60-66. doi:10.1093/emph/eoy005

28. Chhibber S, Kaur S, Kumari S. Therapeutic potential of bacteriophage in treating Klebsiella pneumoniae B5055-mediated lobar pneumonia in mice. J Med Microbiol. 2008;57(12):1508-1513. doi:10.1099/jmm.0.2008/002873-0

29. Curtin JJ, Donlan RM. Using bacteriophages to reduce formation of catheter-associated biofilms by Staphylococcus epidermidis. Antimicrob Agents Chemother. 2006;50(4):1268-1275. doi:10.11 28/AAC.50.4.1268-1275.2006

30. Kumari S, Harjai K, Chhibber S. Efficacy of bacteriophage treatment in murine burn wound infection induced by Klebsiella pneumoniae. J Microbiol Biotechnol. 2009;19(6):622-628. doi:10.4014/jmb.0808.493

31. Kumari S, Harjai K, Chhibber S. Bacteriophage treatment of burn wound infection caused by Pseudomonas aeruginosa PAO in BALB/c Mice. Am J Biomed Sci. 2009;385-394. doi:10.5099/ aj090400385
32. Verma V, Harjai K, Chhibber S. Structural changes induced by a lytic bacteriophage make ciprofloxacin effective against older biofilm of Klebsiella pneumoniae. Biofouling. 2010;26 (6):729-737. doi:10.1080/08927014.2010.511196

33. Qadir MI, Mobeen T, Masood A. Phage therapy: progress in pharmacokinetics. Braz J Pharm Sci. 2018;54(1). doi:10.1590/ s2175-97902018000117093

34. Peng Q, Yuan Y. Characterization of a newly isolated phage infecting pathogenic Escherichia coli and analysis of its mosaic structural genes. Sci Rep. 2018;8(1):8086. doi:10.1038/s41598-018-26004-4

35. Dunne M, Rupf B, Tala M, et al. Reprogramming bacteriophage host range through structure-guided design of chimeric receptor binding proteins. Cell Rep. 2019;29(5):1336-1350.e4. doi:10.1016/j.celrep.2019.09.062

36. Mahichi F, Synnott AJ, Yamamichi K, Osada T, Tanji Y. Sitespecific recombination of T2 phage using IP008 long tail fiber genes provides a targeted method for expanding host range while retaining lytic activity. FEMS Microbiol Lett. 2009;295 (2):211-217. doi:10.1111/j.1574-6968.2009.01588.x

37. Di Giovine M, Salone B, Martina Y, et al. Binding properties, cell delivery, and gene transfer of adenoviral penton base displaying bacteriophage. Virology. 2001;282(1):102-112. doi:10.1006/viro.2000.0809

38. Lu TK, Collins JJ. Dispersing biofilms with engineered enzymatic bacteriophage. Proc Natl Acad Sci U S A. 2007;104 (27):11197-11202. doi:10.1073/pnas.0704624104

39. WHO. WHO | Ten years in public health 2007-2017. WHO; 2017. Available from: http://www.who.int/publications/10-yearreview/en/. Accessed September 1, 2020.

40. Butler MS, Blaskovich MA, Cooper MA. Antibiotics in the clinical pipeline at the end of 2015. J Antibiot. 2017;70(1):3-24. doi:10.1038/ja.2016.72

41. Slopek S, Beata W-D, Dabrowski M, Ali na -K-K. Result of bacteriophage treatment of suppurative bacterial infections in the years 1981-1986. Arch Immunol Ther Exp (Warsz). 1987;35(5):15.

42. Sulakvelidze A, Alavidze Z, Morris JG. Bacteriophage therapy. Antimicrob Agents Chemother. 2001;45(3):649-659. doi:10.1128/ AAC.45.3.649-659.2001

43. Lin DM, Koskella B, Lin HC. Phage therapy: an alternative to antibiotics in the age of multi-drug resistance. WJGPT. 2017;8 (3):162. doi:10.4292/wjgpt.v8.i3.162

44. Carlton RM. Phage therapy: past history and future prospects. Arch Immunol Ther Exp (Warsz). 1999;47(5):267-274.

45. Abedon ST. Phage-antibiotic combination treatments: antagonistic impacts of antibiotics on the pharmacodynamics of phage therapy? Antibiotics (Basel). 2019;8(4). doi:10.3390/antibiotics8040182

46. Taylor M, Razieh K, Sandra M, Michael JR Bacteriophageantibiotic combinations: a promising alternative for refractory infections? ContagionLive; February 19, 2020. Available from: https://www.contagionlive.com/publications/contagion/2020/febru ary/bacteriophageantibiotic-combinations-a-promising-alternativefor-refractory-infections. Accessed September 1, 2020.

47. Merabishvili M, Vos DD, Verbeken G, et al. Selection and characterization of a candidate therapeutic bacteriophage that lyses the Escherichia coli O104: h4Strain from the 2011 outbreak in Germany. PLoS One. 2012;7(12):e52709. doi:10.1371/journal. pone. 0052709

48. McVay CS, Velásquez M, Fralick JA. Phage therapy of Pseudomonas aeruginosa infection in a mouse burn wound model. Antimicrob Agents Chemother. 2007;51(6):1934-1938. doi:10.1128/AAC.01028-06

49. Markoishvili K, Tsitlanadze G, Katsarava R, Morris JG, Sulakvelidze A. A novel sustained-release matrix based on biodegradable poly(ester amide)s and impregnated with bacteriophages and an antibiotic shows promise in management of infected venous stasis ulcers and other poorly healing wounds. Int $J$ Dermatol. 2002;41(7):453-458. doi:10.1046/ j.1365-4362.2002.01451.x 
50. Międzybrodzki R, Harper DR, Abedon ST, et al. Current Updates from the Long-Standing Phage Research Centers in Georgia, Poland, and Russia. Springer International Publishing; 2018. doi:10.1007/978-3-319-40598-8_31-1

51. Jończyk E, Kłak M, Międzybrodzki R, Górski A. The influence of external factors on bacteriophages-review. Folia Microbiol. 2011;56(3):191-200. doi:10.1007/s12223-011-0039-8

52. WHO. WHO | Health data and statistics. WHO; November 2013. Available from: http://www.who.int/healthinfo/statistics/en/. Accessed October 3, 2020.

53. Liu L, Oza S, Hogan D, et al. Global, regional, and national causes of child mortality in 2000-13, with projections to inform post-2015 priorities: an updated systematic analysis. Lancet. 2015;385(9966):430-440. doi:10.1016/S0140-6736(14)61698-6

54. Kotloff KL, Winickoff JP, Ivanoff B, et al. Global burden of Shigella infections: implications for vaccine development and implementation of control strategies. Bull World Health Organ. 1999;16.

55. Gudina I, Gizachew Z, Woyessa D, Kassa T. Isolation of bacteriophage and assessment of its activity against biofilms of uropathogenic Escherichia coli in Jimma Town, South Western Ethiopia. Am J Curr Microbiol. 2018;6(1):52-66.

56. Hailemichael T. Isolation of bacteriophage against biofilm forming and MDR Acinetobacter baumannii from surface of medical equipment and floor in Jimma University Medical Center, South West, Ethiopia \{disseration\}. Jimma, Jimma University; January 2020 .

57. Kakou-Ngazoa ES, Audrey AA, Krylova K, et al. First novel phages from rodents with lytic activity on clinical Enterobacteriaceae strains: initiation for phage therapy in West Africa. Afr J Microbiol Res. 2020;14(6):280-285. doi:10.5897/AJMR2020.9329

58. Leta A, Yohannes M, Kassa T. Assessment of therapeutic potential of bacteriophages to control Escherichia coli infection in Swiss mice model. Ethiop J App Sci Tech. 2017;8(2):73-83.

59. Maina AN, Mwaura FB, Oyugi J, Goulding D, Toribio AL, Kariuki S. Characterization of Vibrio cholerae bacteriophages isolated from the environmental waters of the Lake Victoria Region of Kenya. Curr Microbiol. 2014;68(1):64-70. doi:10.1007/s00284-013-0447-x

60. Abul-Hassan HS, El-Tahan K, Gomaa R, Massoud B. Bacteriophage therapy of pseudomonas burn wound sepsis. Ann Burns Fire Disasters. 1990;3(4).

61. Simpkin VL, Renwick MJ, Kelly R, Mossialos E. Incentivising innovation in antibiotic drug discovery and development: progress, challenges and next steps. J Antibiot (Tokyo). 2017;70 (12):1087-1096. doi:10.1038/ja.2017.124

62. Edqvist L-E, Pedersen KB. 9. Antimicrobials as growth promoters: resistance to common sense. In: Harremoës P et al. Late Lessons from Early Warnings: The Precautionary Principle 18962000. EU; 2002:223. Available from: https://www.eea.europa.eu/ publications/environmental_issue_report_2001_22. Accessed October 20, 2020.

63. Roth N, Käsbohrer A, Mayrhofer S, Zitz U, Hofacre C, Domig KJ. The application of antibiotics in broiler production and the resulting antibiotic resistance in Escherichia coli: a global overview. Poult Sci. 2019;98(4):1791-1804. doi:10.3382/ps/pey539

64. Van TTH, Yidana Z, Smooker PM, Coloe PJ. Antibiotic use in food animals worldwide, with a focus on Africa: pluses and minuses. J Glob Antimicrob Resist. 2020;20:170-177. doi:10.10 16/j.jgar.2019.07.031

65. Golkar Z, Bagasra O, Pace DG. Bacteriophage therapy: a potential solution for the antibiotic resistance crisis. $J$ Infect Dev Ctries. 2014;8(2):129-136. doi:10.3855/jidc.3573

66. Gigante A, Atterbury RJ. Veterinary use of bacteriophage therapy in intensively-reared livestock. Virol J. 2019;16(1):155. doi:10.1186/s12985-019-1260-3
67. Wittebole X, De Roock S, Opal SM. A historical overview of bacteriophage therapy as an alternative to antibiotics for the treatment of bacterial pathogens. Virulence. 2014;5(1):226-235. doi:10.4161/viru.25991

68. Smith HW, Huggins MB. Successful treatment of experimental Escherichia coli infections in mice using phage: its general superiority over antibiotics. Microbiology. 1982;128(2):307-318. doi:10.1099/00221287-128-2-307

69. Smith HMB, Shaw KM. The control of experimental Escherichia coli diarrhoea in calves by means of bacteriophages. J Gen Microbiol. 1987;133(5):1111-1126. doi:10.1099/00221287-133-5-1111

70. Grinyova K.Application of biological bacteriophage-based for diagnosis, prevention and treatment of fish pseudomonosis. Eur Stud Sci J. 2014;2.

71. Wernicki A, Nowaczek A, Urban-Chmiel R. Bacteriophage therapy to combat bacterial infections in poultry. Virol J. 2017;14 (1):179. doi:10.1186/s12985-017-0849-7

72. Svircev A, Roach D, Castle A. Framing the future with bacteriophages in agriculture. Viruses. 2018;10(5):5. doi:10.3390/ v10050218

73. Johnson TJ, Shank JM, Johnson JG. Current and potential treatments for reducing campylobacter colonization in animal hosts and disease in humans. Front Microbiol. 2017;8. doi:10.3389/ fmicb.2017.00487.

74. Narayanasamy P. Microbial Plant Pathogens-Detection and Disease Diagnosis: Bacterial and Phytoplasmal Pathogens, Vol. 2. Netherlands: Springer; 2011. doi:10.1007/978-90-481-9769-9

75. Mendonça L, Zambolim L, Jl B Bacterial citrus diseases: major threats and recent progress. J Bacteriol Mycol. 2017;5:4-2017. doi:10.15406/JBMOA.2017.05.00143

76. Besarab NV. Can bacteriophages combat bacterial diseases of plants? 2018. Available from: http://www.global-engage.com/agri cultural-biotechnology/bacteriophages-combat-bacterial-diseasesplants/. Accessed September 5, 2020.

77. Pinheiro LAM, Pereira C, Frazão C, Balcão VM, Almeida A. Efficiency of phage $\varphi 6$ for biocontrol of Pseudomonas syringae pv. Syringae: an in vitro preliminary study. Microorganisms. 2019;7(9). doi:10.3390/microorganisms 7090286

78. Sarhan WA, Azzazy HM. Phage approved in food, why not as a therapeutic? Expert Rev Anti Infect Ther. 2015;13(1):91-101. doi:10.1586/14787210.2015.990383

79. Park SC, Nakai T. Bacteriophage control of Pseudomonas plecoglossicida infection in ayu, Plectoglossis altivelis. Dis Aquat Org. 2003;53:33-39. doi:10.3354/dao053033

80. Schnabel EL, Jones AL. Isolation and characterization of FiveErwinia amylovora bacteriophages and assessment of phage resistance in strains of Erwinia amylovora. Appl Environ Microbiol. 2001;67(1):59-64. doi:10.1128/AEM.67.1.59-64.2001

81. Wei C, Liu J, Maina AN, et al. Developing a bacteriophage cocktail for biocontrol of potato bacterial wilt. Virol Sin. 2017;32(6):476-484. doi:10.1007/s12250-017-3987-6

82. Cycon M, Mrozik A, Piotrowska-Seget Z. Antibiotics in the soil environment — degradation and their impact on microbial activity and diversity. Front Microbiol. 2019;10. doi:10.3389/fmicb.2019.00338.

83. Jones JB, Vallad GE, Iriarte FB, et al. Considerations for using bacteriophages for plant disease control. Bacteriophage. 2012;2 (4):e23857. doi:10.4161/bact.23857

84. Civerolo EL, Keil HL. Inhibition of bacterial spot of peach foliage by Xanthomonas pruni bacteriophage. Phytopathology. 1969.

85. Erskine JM. Characteristics of Erwinia amylovora bacteriophage and its possible role in the epidemiology of fire blight. Can J Microbiol. 1973;19(7):837-845. doi:10.1139/m73-134

86. Ritchie D, Klos E Isolation of Erwinia amylovora bacteriophage from aerial parts of apple trees. Phytopathology. 1977;36:101-104. doi:10.1094/Phyto-67-101 
87. Gill JJ, Svircev AM, Smith R, Castle AJ. Bacteriophages of Erwinia amylovora. Appl Environ Microbiol. 2003;69 (4):2133-2138. doi:10.1128/AEM.69.4.2133-2138.2003

88. Malnoy M, Faize M, Venisse J-S, Geider K, Chevreau E. Expression of viral EPS-depolymerase reduces fire blight susceptibility in transgenic pear. Plant Cell Rep. 2005;23(9):632-638. doi:10.1007/s00299-004-0855-2

89. Sharma R, Pielstick BA, Bell KA, et al. A novel, highly related jumbo family of bacteriophages that were isolated against Erwinia. Front Microbiol. 2019;10:1533. doi:10.3389/fmicb.2019.01533

90. Marcó MB, Reinheimer JA, Quiberoni A. Phage adsorption to Lactobacillus plantarum: influence of physiological and environmental factors. Int J Food Microbiol. 2010;138(3):270-275. doi:10.1016/j.ijfoodmicro.2010.01.007

91. Ly-Chatain MH. The factors affecting effectiveness of treatment in phages therapy. Front Microbiol. 2014;5. doi:10.3389/ fmicb.2014.00051.

92. Watanabe R, Matsumoto T, Sano G, et al. Efficacy of bacteriophage therapy against gut-derived sepsis caused by Pseudomonas aeruginosa in mice. Antimicrob Agents Chemother. 2007;51 (2):446-452. doi:10.1128/AAC.00635-06

93. Hendrix RW. Bacteriophage genomics. Curr Opin Microbiol. 2003;6(5):506-511. doi:10.1016/j.mib.2003.09.004

94. Hayes S, Mahony J, Nauta A, van Sinderen D. Metagenomic approaches to assess bacteriophages in various environmental niches. Viruses. 2017;9(6):6. doi:10.3390/v9060127

95. Czajkowski R, Jackson RW, Lindow SE. Editorial: environmental bacteriophages: from biological control applications to directed bacterial evolution. Front Microbiol. 2019;10:1830. doi:10.3389/ fmicb.2019.01830

96. Clokie M PHAGE | Mary Ann Liebert, Inc., publishers. nn Liebert; 2020. Available from: https://home.liebertpub.com/publi cations/phage/652/overview\#aims. Accessed September 3, 2020

97. Francis T. Bacteriophage aims \& scope. Bacteriophages. 2020.

98. NCBI P. (Bacteriophage[MeSH Terms]) AND "last 10 years"[PDat] - PMC - NCBI; 2020. Available from: https:// www.ncbi.nlm.nih.gov/pmc/?term $=$ (Bacteriophage $\% 5 \mathrm{BMeSH}$ + Terms $\% 5$ D) + AND $+\% 22$ last $+10+$ years $\% 22 \% 5$ BPDat $\% 5$ D. Accessed September 3, 2020.

99. ISO. Water quality - detection and enumeration of bacteriophages - part 1: enumeration of F-specific RNA bacteriophages. ISO; 2017. Available from: https://www.iso.org/cms/render/live/ en/sites/isoorg/contents/data/standard/01/87/18794.html. Accessed September 1, 2020.

100. Olszak T, Latka A, Roszniowski B, Valvano MA, Drulis-Kawa Z. Phage life cycles behind bacterial biodiversity. Curr Med Chem. 2017;24(36):3987-4001. doi:10.2174/0929867324666170413100 136

101. Olsen JE, Brown DJ, Skov MN, Christensen JP. Bacterial typing methods suitable for epidemiological analysis. applications in investigations of salmonellosis among livestock. Vet $Q$. 1993;15 (4):125-135. doi:10.1080/01652176.1993.9694390

102. Mohammed M. Phage typing or CRISPR typing for epidemiological surveillance of Salmonella Typhimurium? BMC Res Notes. 2017;10(1):1-7. doi:10.1186/s13104-017-2878-0

103. Fauconnier A. Phage therapy regulation: from night to dawn. Viruses. 2019;11(4):352. doi:10.3390/v11040352

104. Viridax. Viridax ${ }^{\mathrm{TM}} ; 2020$. Availabble from: http://www.dreamingrock. com/viridax/eviridax/cphage.htm. Accessed September 3, 2020.

105. WHO, editor. Quality Assurance of Pharmaceuticals: A Compendium of Guidelines and Related Materials. Volume 2: Good Manufacturing Practices and Inspection. 2nd updated ed. World Health Organization; 2007.

106. Intestifag. Intestifag ${ }^{\circledR}$ polyvalent bacteriophage. Bacteriophages; 2020. Available from: https://bacteriophages.info/en/bacterioph age/intesifag/. Accessed September 3, 2020.
107. Abedon. Phage Companies - Bacteriophage Ecology Group. Phage companies; 2018. Available from: http://companies.phage. org/. Accessed September 3, 2020.

108. Verbeken G, De Vos D, Vaneechoutte M, Merabishvili M, Zizi M, Pirnay J-P. European regulatory conundrum of phage therapy. Future Microbiol. 2007;2(5):485-491. doi:10.2217/17460913.2. 5.485

109. García R, Latz S, Romero J, Higuera G, García K, Bastías R. Bacteriophage production models: an overview. Front Microbiol. 2019;10:1187. doi:10.3389/fmicb.2019.01187

110. Perepanova TS, Darbeeva OS, Kotliarova GA, et al. [The efficacy of bacteriophage preparations in treating inflammatory urologic diseases]. Urol Nefrol (Mosk). 1995;5:14-17. Russian.

111. Nikolich MP, Filippov AA. Bacteriophage therapy: developments and directions. Antibiotics (Basel). 2020;9:3. doi:10.3390/ antibiotics9030135

112. Rose T, Verbeken G, Vos DD, et al. Experimental phage therapy of burn wound infection: difficult first steps. Int J Burns Trauma. 2014;4(2):66-73.

113. Kochetkova VA, Mamontov AS, Moskovtseva RL, et al. [Phagotherapy of postoperative suppurative-inflammatory complications in patients with neoplasms]. Sov Med. 1989;6:23-26. Russian.

114. Fadlallah A, Chelala E, Legeais J-M. Corneal Infection Therapy with Topical Bacteriophage Administration. Open Ophthalmol J. 2015;9(1):167-168. doi:10.2174/1874364101509010167

115. Fish R, Kutter E, Wheat G, Blasdel B, Kutateladze M, Kuhl S. Bacteriophage treatment of intransigent diabetic toe ulcers: a case series. J Wound Care. 2016;25(Sup7):S27-S33. doi:10.12968/ jowc.2016.25.Sup7.S27

116. Sarker SA, Sultana S, Reuteler G, et al. Oral phage therapy of acute bacterial diarrhea with two coliphage preparations: a randomized trial in children from Bangladesh. EBioMedicine. 2016;4:124-137. doi:10.1016/j.ebiom.2015.12.023

117. Jun JW, Shin TH, Kim JH, et al. Bacteriophage therapy of a Vibrio parahaemolyticus infection caused by a multipleantibiotic-resistant O3: K6 pandemic clinical strain. J Infect Dis. 2014;210(1):72-78. doi:10.1093/infdis/jiu059

118. Wills QF, Kerrigan C, Soothill JS. Experimental bacteriophage protection against Staphylococcus aureus abscesses in a rabbit model. Antimicrob Agents Chemother. 2005;49(3):1220-1221. doi:10.1128/AAC.49.3.1220-1221.2005

119. El-Gohary F, We H, Gr H, Nc R, Zy Z, Am D. Environmental augmentation with bacteriophage prevents colibacillosis in broiler chickens. Poult Sci. 2014;93(11):2788-2792. doi:10.3382/ ps.2014-04282

120. Park SC, Shimamura I, Fukunaga M, Mori K-I, Nakai T. Isolation of bacteriophages specific to a fish pathogen, Pseudomonas plecoglossicida, as a candidate for disease control. Appl Environ Microbiol. 2000;66 (4):1416-1422. doi:10.1128/AEM.66.4.1416-1422.2000

121. Akmal M, Rahimi-Midani A, Hafeez-ur-Rehman M, Hussain A, Choi T-J. Isolation, characterization, and application of a bacteriophage infecting the fish pathogen Aeromonas hydrophila. Pathogens. 2020;9(3):215. doi:10.3390/pathogens9030215

122. Sheng H, Knecht HJ, Kudva IT, Hovde CJ. Application of bacteriophages to control intestinal Escherichia coli O157: H7Levels in ruminants. Appl Environ Microbiol. 2006;72(8):5359-5366. doi:10.1128/AEM.00099-06

123. Adriaenssens EM, Van Vaerenbergh J, Vandenheuvel D, et al. T4related bacteriophage LIMEstone isolates for the control of soft rot on potato caused by 'Dickeya solani.' Johnson EA, ed. PLoS One. 2012;7(3):e33227. doi:10.1371/journal.pone.0033227

124. Fujiwara A, Fujisawa M, Hamasaki R, Kawasaki T, Fujie M, Yamada T. Biocontrol of Ralstonia solanacearum by treatment with lytic bacteriophages. Appl Environ Microbiol. 2011;77 (12):4155-4162. doi:10.1128/AEM.02847-10 
125. Obradovic A, Jones JB, Momol MT, Balogh B, Olson SM Management of tomato bacterial spot in the field by foliar applications of bacteriophages and SAR inducers. Plant Dis. 2004;88 (7):736-740. doi:10.1094/PDIS.2004.88.7.736

126. Das M, Bhowmick TS, Ahern SJ, Young R, Gonzalez CF. Control of pierce's disease by phage. PLoS One. 2015;10(6):6. doi:10.1371/journal.pone. 0128902

127. Lang JM, Gent DH, Schwartz HF. Management of Xanthomonas leaf blight of onion with bacteriophages and a plant activator. Plant Dis. 2007;91(7):871-878. doi:10.1094/PDIS-91-7-0871
128. Lim J-A. Biocontrol of Pectobacterium carotovorum subsp. carotovorum using bacteriophage PP1. J Microbiol Biotechnol. 2013;23(8):1147-1153. doi:10.4014/jmb.1304.04001

129. Goyer C. Isolation and characterization of phages Stsc1 and Stsc3 infecting Streptomyces scabiei and their potential as biocontrol agents. Can J Plant Pathol. 2005;27(2):210-216. doi:10.1080/ 07060660509507218

130. Balogh B, Canteros BI, Stall RE, Jones JB. Control of citrus canker and citrus bacterial spot with bacteriophages. Plant Dis. 2008;92(7):1048-1052. doi:10.1094/PDIS-92-7-1048

\section{Publish your work in this journal}

Infection and Drug Resistance is an international, peer-reviewed openaccess journal that focuses on the optimal treatment of infection (bacterial, fungal and viral) and the development and institution of preventive strategies to minimize the development and spread of resistance. The journal is specifically concerned with the epidemiology of antibiotic resistance and the mechanisms of resistance development and diffusion in both hospitals and the community. The manuscript management system is completely online and includes a very quick and fair peerreview system, which is all easy to use. Visit http://www.dovepress.com/ testimonials.php to read real quotes from published authors. 